\title{
Nucleotide Sequence and Expression of the Mouse Corticotropin-Releasing Hormone Gene
}

\author{
Audrey F. Seasholtz, ${ }^{*} \dagger$ Francis J. Bourbonais, ${ }^{*}$ Catherine E. Harnden, $\ddagger$ ANd Sally A. Camper $\ddagger$ \\ *Mental Health Research Institute, $\dagger$ Department of Biological Chemistry, and $\ddagger$ Department of Human Genetics, \\ University of Michigan, Ann Arbor, Michigan 48109
}

Received for publication May 15, 1991

\begin{abstract}
The mouse corticotropin-releasing hormone (CRH) gene has been isolated and characterized by DNA sequence analysis. The gene exhibits a structural organization similar to that of the human, rat, and ovine genes with two exons and an intervening sequence of 675 base pairs interrupting the $5^{\prime}$ untranslated sequence of the mature mRNA. Analysis of the nucleotide sequence reveals that the mouse CRH peptide is identical at the amino acid level to the human and rat CRH peptides, with only three nucleotide changes between the rat and mouse sequences within the CRH peptide-encoding region. Additionally, the mouse CRH gene exhibits greater than 92\% homology to the rat, human, and ovine CRH genes within the first 336 nucleotides of $5^{\prime}$ flanking DNA, suggesting that this sequence contains important transcriptional control elements which have been conserved across species to mediate the regulation of this important neuroendocrine peptide. The expression of the mouse CRH gene in brain is demonstrated using in situ hybridization analysis. Mouse CRH mRNA can be detected in the paraventricular nucleus of the hypothalamus and inferior olivary nucleus of mouse brain. 1991 Academic Press, Inc.
\end{abstract}

\section{INTRODUCTION}

The mammalian stress response is mediated in large part via the hypothalamic-anterior pituitary-adrenal (HPA) axis. The key hypothalamic-releasing factor in this axis is corticotropin-releasing hormone (CRH), a 41 amino acid peptide originally isolated and characterized by Vale and co-workers $(1,2)$. Release of $\mathrm{CRH}$ from the median eminence causes increased synthesis of proopiomelanocortin and secretion of adrenocorticotropin in the anterior pituitary, resulting in increased production of glucocorticoids in the adrenal cortex. In addition to the role of $\mathrm{CRH}$ in the HPA stress axis, $\mathrm{CRH}$ has also been shown to influence behavioral, neuroendocrine, and autonomic responses to stress within the central nervous system (3-5).

Because CRH plays such an important role in the body's response to stress, an understanding of the molecular mechanisms controlling the expression of the $\mathrm{CRH}$ precursor and its gene is essential. These studies require the use of CRH cDNA and genomic sequences. The human, rat, and ovine CRH cDNA and genes have previously been isolated and sequenced (6-11). We are currently using transgenic mice to localize the cis-acting DNA control elements responsible for the tissue-specific expression of the $\mathrm{CRH}$ gene. In order to clearly discriminate between the $\mathrm{CRH}$ transgene and the endogenous $\mathrm{CRH}$ gene, we have elucidated the entire nucleotide sequence of the mouse CRH gene including 336 bp of $5^{\prime}$ flanking DNA. The mouse CRH gene is highly homologous to the rat $\mathrm{CRH}$ gene in all regions analyzed, while demonstrating high degrees of homology with the human and ovine CRH sequences in the $5^{\prime}$ flanking DNA and CRH peptide-encoding regions. In fact, the predicted sequence of the mouse $\mathrm{CRH}$ peptide is identical at the amino acid level to the human and rat $\mathrm{CRH}$ peptides. Additionally, we demonstrate the expression of the mouse $\mathrm{CRH}$ gene in the mouse brain by in situ hybridization histochemistry.

\section{MATERIALS AND METHODS}

\section{Screening of a Mouse Genomic DNA Library}

A mouse genomic library (Clontech, mouse Balb/c liver) was plated on Escherichia coli NM 538 cells and screened in duplicate using a random primed rat $\mathrm{CRH}$ cDNA BamHI fragment (761 bp) as hybridization probe. This 761-bp BamHI fragment was isolated from the rat $\mathrm{CRH}$ cDNA clone (10) and subcloned into pGEM3Z (Promega) to create pGEM3ZBam761. Hybridization was carried out at $37^{\circ} \mathrm{C}$ in $50 \%$ formamide, $5 \times \mathrm{SSC}, 25 \mathrm{mM}$ sodium phosphate (pH 6.5), $5 \times$ Denhardts, $5 \mathrm{mM}$ EDTA, $0.1 \%$ sodium pyrophosphate, and $0.1 \%$ SDS for $20 \mathrm{~h}$. The filters were washed in $2 \times \mathrm{SSC}, 0.1 \%$ SDS for $15 \mathrm{~min}$ each at 25 and $37^{\circ} \mathrm{C}$ followed by a 30 -min wash in $0.5 \times$ SSC, $0.1 \%$ SDS at $48^{\circ} \mathrm{C}$. The filters were autoradiographed for $60 \mathrm{~h}$ at $-80^{\circ} \mathrm{C}$ with intensifying screens. Hybridization-positive plaques were picked and plaque-purified. Phage DNA was purified, digested with various restriction enzymes, and analyzed by Southern blotting using rat $\mathrm{CRH}$ genomic 
fragments for hybridization probes. Hybridization-positive mouse genomic DNA fragments were isolated and ligated into M13 or pUC vectors for restriction mapping, subcloning, and DNA sequencing. DNA sequencing was performed with Sequenase Version 2.0 (U.S. Biochemical) using dGTP and dITP mixes as described by the manufacturer. The Genetics Computer Group (GCG) Sequence Analysis Software Package (GAP program) was used for nucleotide homology determinations.

\section{Southern Blot}

Mouse genomic DNA was purified from mouse liver. DNA samples $(20 \mu \mathrm{g})$ were digested with appropriate restriction enzymes and the resulting DNA fragments were separated on a $0.8 \%$ agarose gel in TEB buffer $(89 \mathrm{mM}$ Tris base, $89 \mathrm{mM}$ boric acid, $2 \mathrm{mM}$ ED'TA, pH 8.2). The DNA was denatured and neutralized as described by Southern (12). The gel was transferred to Nytran (Schleicher and Schuell) and hybridized with either a mouse CRH 578-bp PstI DNA fragment (nick-translated) containing the mouse CRH peptide sequence (see Fig. 1) or the rat CRH 761-bp BamHI fragment (nick-translated) used for screening the genomic library. The blots were hybridized at $55^{\circ} \mathrm{C}$ (rat CRH probe) or $62^{\circ} \mathrm{C}$ (mouse CRH probe) for $18 \mathrm{~h}$ in $5 \times \mathrm{SSC}, 25 \mathrm{mM}$ sodium phosphate (pH $6.5), 5 \times$ Denhardts, $5 \mathrm{mM}$ EDTA, $0.1 \%$ sodium pyrophosphate, $0.1 \% \mathrm{SDS}$, and $50 \mu \mathrm{g} / \mathrm{ml}$ yeast RNA. The filters were washed two times at room temperature in $2 \times$

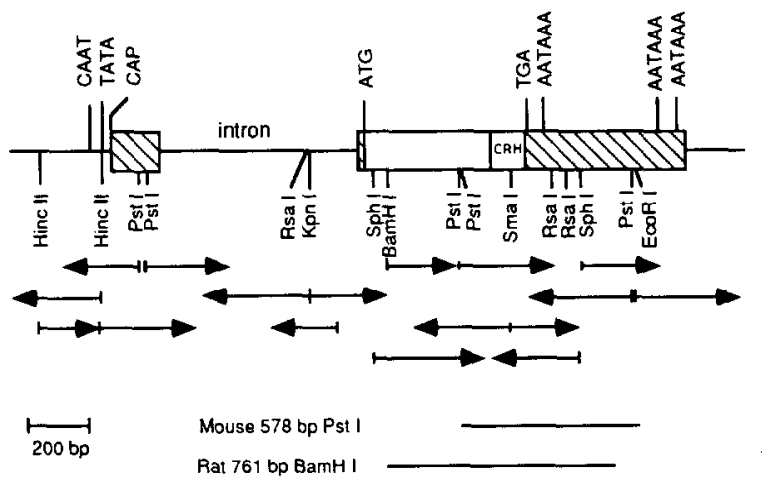

FIG. 1. Structural organization of the mouse $\mathrm{CRH}$ gene. The locations of the two exons are indicated by closed boxes. The hatched regions of the exons denote either $5^{\prime}$ or $3^{\prime}$ untranslated sequences. The translation initiation codon (ATG) and translation termination codon (TGA) for the CRH protein precursor are shown. The position of the 41 amino acid CRH peptide within the precursor is denoted by CRH. The putative transcription initiation site is shown by CAP and the positions of the CAAT box and TATAA box promoter elements and poly(A) addition signals (AATAAA) are shown. The structure of exon 2 shown above assumes usage of the third poly(A) addition sequence. Restriction enzyme sites utilized for nucleotide sequence analysis are shown below the schematic diagram (not all sites for each restriction enzyme are shown). The horizontal arrows beneath the restriction map indicate the direction and extent of nucleotide sequence determinations. The positions of the 578-bp mouse PstI fragment and rat 761-bp BamHI fragment are also shown below the schematic diagram of the mouse CRH gene.

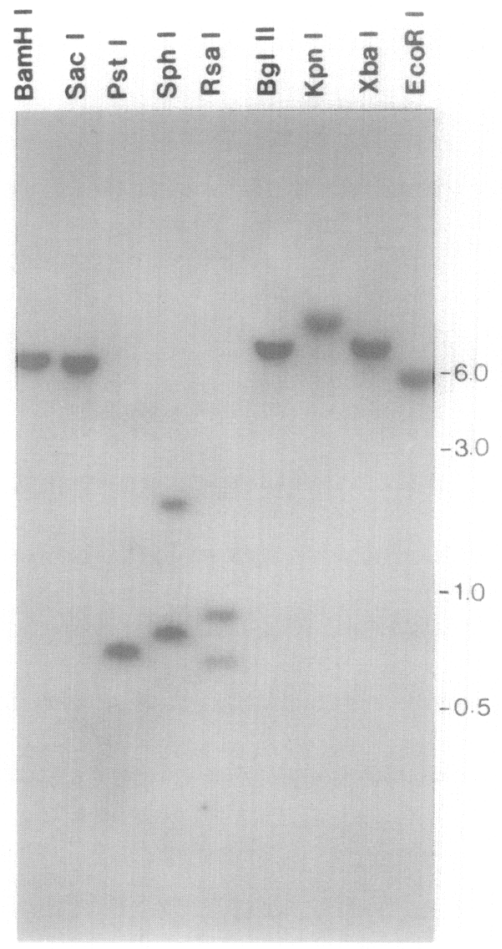

FIG. 2. Southern blot analysis of mouse genomic DNA. Mouse liver DNA was digested with the indicated restriction endonucleases, electrophoresed through a $0.8 \%$ agarose gel, transferred to nylon membrane, and hybridized with the nick-translated mouse PstI 578-bp fragment as described under Materials and Methods. The autoradiogram shown was exposed at $-80^{\circ} \mathrm{C}$ for $20 \mathrm{~h}$ with an intensifying screen. The sizes (in kilobases) of several DNA fragments from the 1-kb ladder (BRL) are shown at the right of the figure.

SSC, $0.1 \%$ SDS and then for $1 \mathrm{~h}$ at 55 or $62^{\circ} \mathrm{C}$ in $0.2 \times$ $\mathrm{SSC}, 0.1 \% \mathrm{SDS}$ for the rat and mouse CRH probes, respectively. The filters were air-dried and exposed to $\mathrm{X}$ ray film at $-80^{\circ} \mathrm{C}$ with intensifying screens.

\section{In Situ Hybridization Analysis}

Mouse brains were removed, frozen in 2-methylbutane, and stored at $-80^{\circ} \mathrm{C}$. The brains were sectioned $(15-\mu \mathrm{m}$ sections) and processed for in situ analysis as previously described (13) with the following minor modifications. After fixation of the sections for $1 \mathrm{~h}$ in cold buffered $4 \%$ paraformaldehyde followed by a 1-min $2 \times \mathrm{SSC}$ wash, the sections were deproteinated batchwise in $1 \mu \mathrm{g} / \mathrm{ml}$ proteinase $\mathrm{K}$ for $10 \mathrm{~min}$ at $37^{\circ} \mathrm{C}$. After deproteination, the sections were washed, acetylated, rinsed, and dehydrated as described (13). The 578-bp mouse PstI fragment containing the CRH peptide-encoding region was subcloned into pGem-4Z (Promega) and the resulting plasmid pGem4ZPst578 was linearized with HindIII for preparation of antisense cRNA probe with SP6 polymerase or $E c o R I$ for preparation of sense $c R N A$ probe with T7 polymerase using $\left[{ }^{35}\right.$ S]UTP. Probe was diluted in hybridization buffer containing $75 \%$ formamide to yield $1,000,000$ 


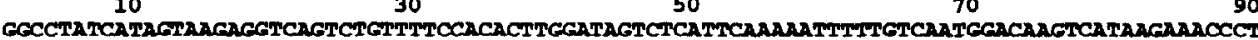

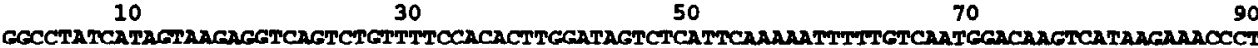

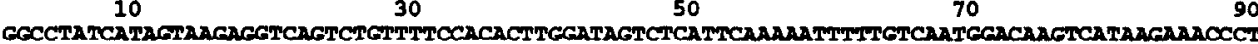

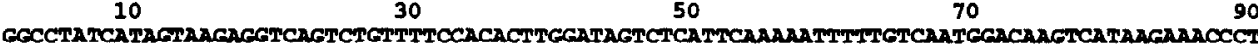

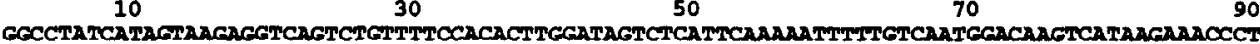
110
130
150
170

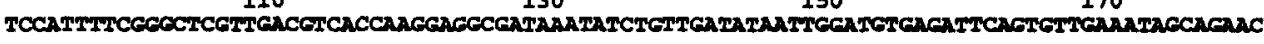

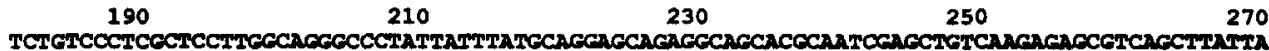

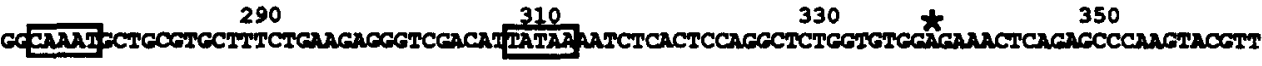
$\begin{array}{cccccc}370 & 390 & 410 & 40\end{array}$

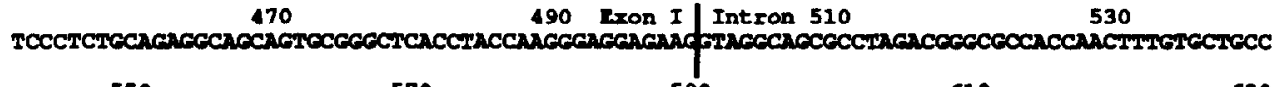

570

610

630

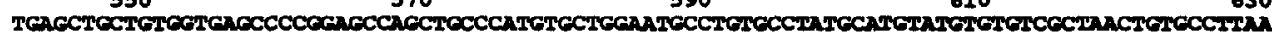

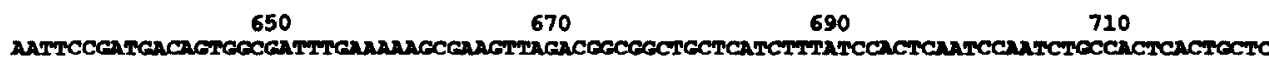

$\begin{array}{cccc}730 & 750 & 770 & 790\end{array}$

$\begin{array}{cccc}730 & 750 & 770 & 790\end{array}$

$\begin{array}{cccc}730 & 750 & 770 & 790\end{array}$

$\begin{array}{cccc}730 & 750 & 770 & 790\end{array}$

$\begin{array}{cccc}730 & 750 & 770 & 790\end{array}$

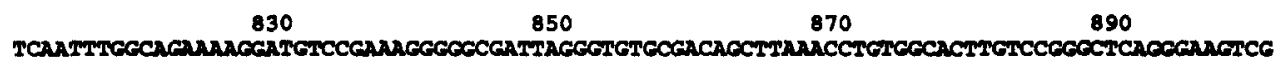

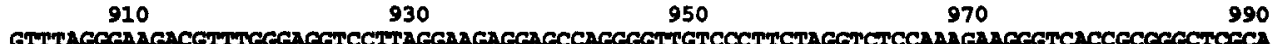
$1010 \quad 1030 \quad 1050 \quad 1070$

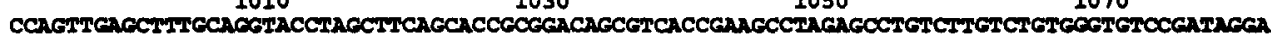

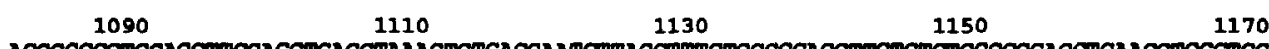

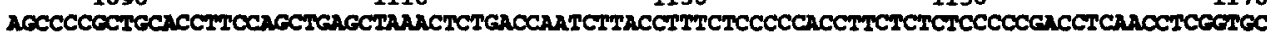

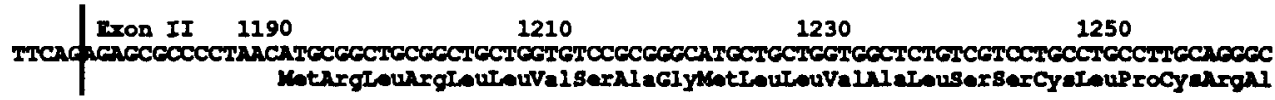

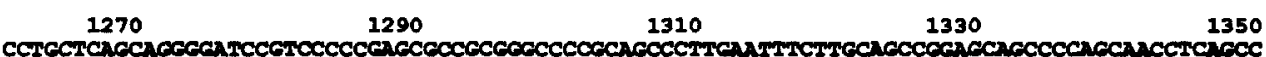

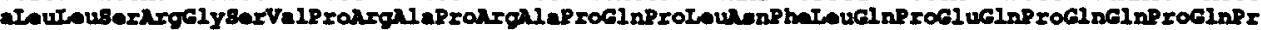

1370

1390

1410

1430

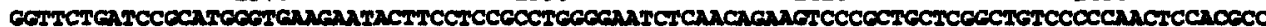

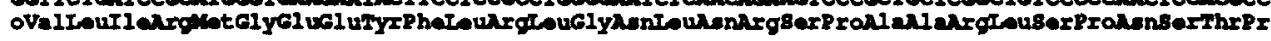

1450 1470

1490

1510

1530

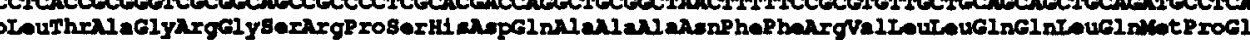

$\begin{array}{llll}1550 & 1570 & 1590 & 1610\end{array}$

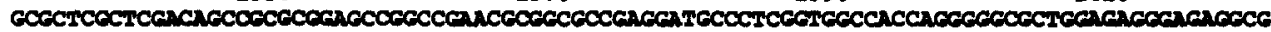

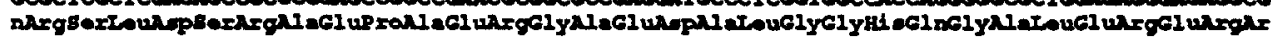
1630 1650 1670 1690 1710

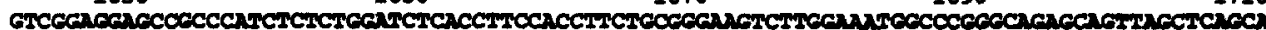

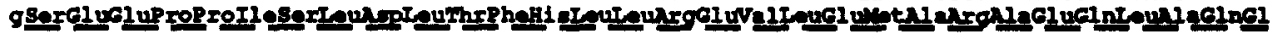
1730

1750 1770

1790 secresoncchachecux

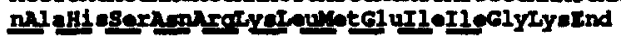

$\begin{array}{lllll}1810 & 1830 & 1850 & 1870 & 1890\end{array}$

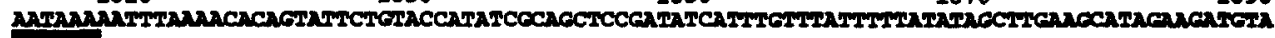

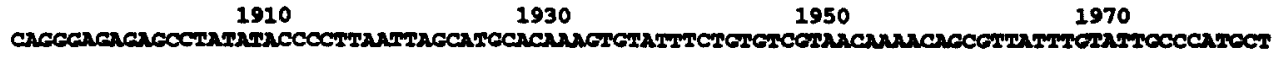
$\begin{array}{cccc}1990 & 2010 & 2030 & 2050\end{array}$

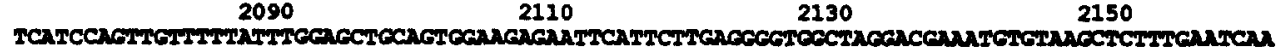

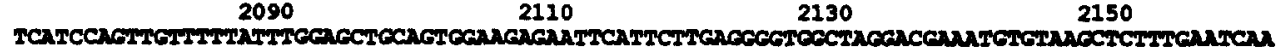

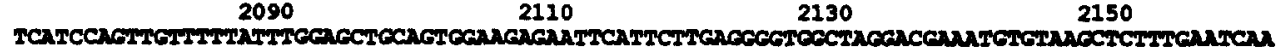

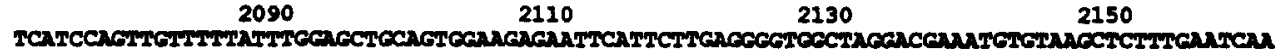

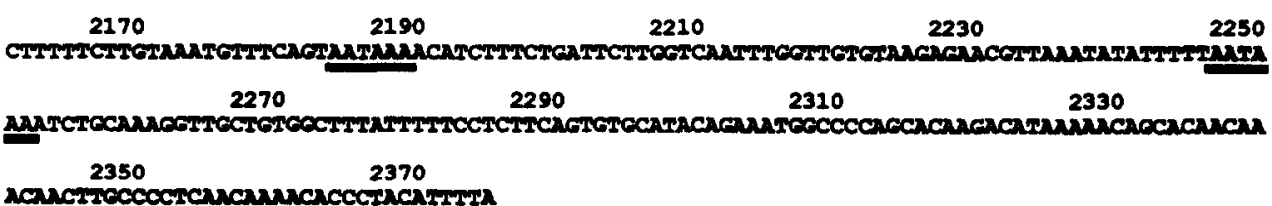

FIG. 3. Nucleotide sequence of the mouse CRH gene. The nucleotide sequence of the message strand is shown along with the deduced amino acid sequence of the CRH precursor. The sequence of the CRH peptide is indicated by the dashed line. The TATAA and CAAT boxes are outlined and the putative cap site is marked by an asterisk. The exon/intron boundaries are denoted by vertical lines and the poly(A) addition sequences are underlined. 
$\mathrm{dpm} / 30 \mu \mathrm{l}$ buffer. Sections were incubated at $54^{\circ} \mathrm{C}$ for $16-20 \mathrm{~h}$. After digestion with RNase A $(200 \mu \mathrm{g} / \mathrm{ml})$ at $37^{\circ} \mathrm{C}$ for $30-60 \mathrm{~min}$, the sections were washed successively in $2 \times \mathrm{SSC}$ and $1 \times \mathrm{SSC}$ for $5 \mathrm{~min}$ each followed by a 60 min wash in $0.5 \times \mathrm{SSC}$ at $60^{\circ} \mathrm{C}$. Sections were then dehydrated through alcohols and exposed to Kodak XAR$5 \mathrm{X}$-ray film for $48 \mathrm{~h}$. Sections were then emulsion-dipped in Kodak NTB2 nuclear emulsion and exposed for 3-4 weeks.

\section{RESULTS AND DISCUSSION}

\section{Isolation of the Mouse CRH Gene}

Approximately 400,000 phage from the mouse genomic library were plated and screened with the 761-bp BamHI fragment of the rat CRH cDNA (Fig. 1) as described under Materials and Methods. Four hybridization-positive plaques were observed. DNA from these recombinant phage was purified, digested with various restriction endonucleases, and analyzed by Southern hybridization. Hybridization probes were selected from various regions of the rat $\mathrm{CRH}$ gene including $5^{\prime}$ flanking DNA, exon I, and exon II sequences. Three of the genomic clones contained unique genomic DNA fragments. However, further analysis demonstrated that all three genomic clones contained common $R s a \mathrm{I}$ and $P s t \mathrm{I}$ hybridization-positive restriction fragments, suggesting that the three clones contained different, but overlapping, genomic DNA fragments representing the same $\mathrm{CRH}$ gene.

\section{Southern Analysis of Mouse Genomic DNA}

To confirm the number of $\mathrm{CRH}$ genes present in the mouse genome and to verify the integrity of the genomic clones, a mouse genomic Southern was performed. Mouse genomic DNA was digested with a number of restriction endonucleases and subjected to Southern blot analysis as described under Materials and Methods. Hybridization with a nick-translated mouse CRH PstI fragment (578 bp containing the $\mathrm{CRH}$ peptide-encoding region) or a nick-translated rat CRH BamHI fragment (see Fig. 1) yielded similar results. The autoradiogram shown in Fig. 2 reveals unique $B a m \mathrm{HI}, S a c \mathrm{I}, P s t \mathrm{I}, B g l \mathrm{II}, K p n \mathrm{I}, X b a \mathrm{I}$,

\section{TABLE 1}

Nucleic Acid Sequence Homologies of Mouse CRH Genomic Sequences to the Corresponding Rat, Human, and Ovine CRH Sequences

\begin{tabular}{llll}
\hline & Rat & Human & Ovine \\
\hline $\begin{array}{c}5^{\prime} \text { Flanking DNA } \\
\quad \text { (Nucleotides 1-336) }\end{array}$ & 98 & 94 & 92 \\
$\begin{array}{c}\text { Exon I (5' untranslated DNA) } \\
\text { (Nucleotides 337-499) }\end{array}$ & 92 & 70 & 63 \\
$\begin{array}{c}\text { Intron } \\
\quad \text { Nucleotides 500-1175) }\end{array}$ & 89 & 70 & 52 \\
$\begin{array}{c}\text { CRH protein precursor } \\
\text { (Nucleotides 1190-1753) }\end{array}$ & 97 & 84 & 76 \\
$\begin{array}{c}\text { CRH peptide } \\
\text { (Nucleotides 1622-1744) }\end{array}$ & 98 & 92 & 82 \\
$3^{\prime}$ Untranslated DNA \\
(Nucleotides 1754-2280)
\end{tabular}

and $E c o$ RI bands after hybridization with the 578-bp PstI fragment from mouse CRH genomic clone No. 1. Multiple hybridization-positive bands are observed in the $S p h I$ and $R s a I$ digests due to the presence of internal $S p h I$ and $R s a I$ restriction enzyme sites in the mouse CRH genomic sequence. The rat CRH BamHI fragment hybridized to the same unique BamHI, SacI, BglII, KpnI, XbaI, and EcoRI restriction fragments as the mouse CRH probe. It also hybridized to the same $R s a \mathrm{I}, S p h \mathrm{I}$, and PstI fragments as the mouse probe and an additional 1.0-kb PstI fragment (data not shown). This hybridization pattern was precisely as expected due to the difference in nucleotide position of the two probes (see Fig. 1). The presence of unique hybridization-positive restriction enzyme fragments and appropriately sized smaller fragments (at the stringencies indicated under Materials and Methods), along with the fact that all positively hybridizing genomic clones shared similar restriction patterns, led us to conclude that a single CRH gene is present in the mouse genome.

\section{Nucleotide Sequence and Structural Organization of the} Mouse CRH Gene

Mouse CRH genomic clone No. 1 was chosen for further analysis. Fragments of the mouse genomic DNA insert from this clone were isolated and subcloned into pUC and

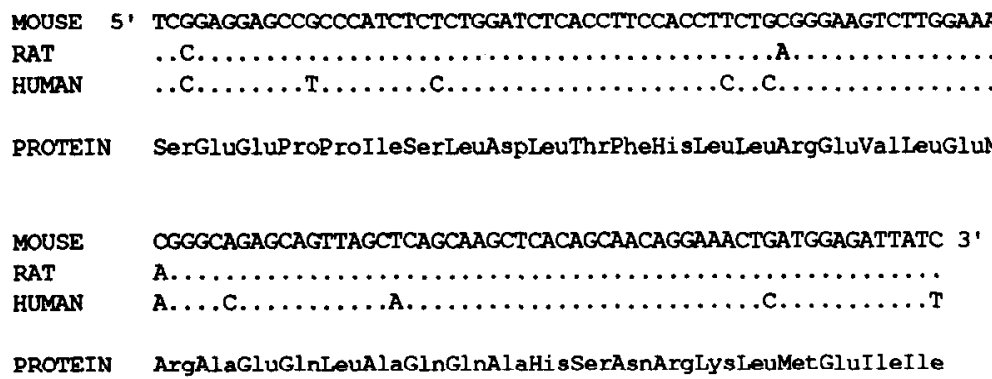

FIG. 4. Nucleic acid sequence homology across the CRH peptide-encoding DNA from the mouse, rat, and human CRH genes. Dots represent conserved nucleotides; only the changes from the mouse sequence are shown. 

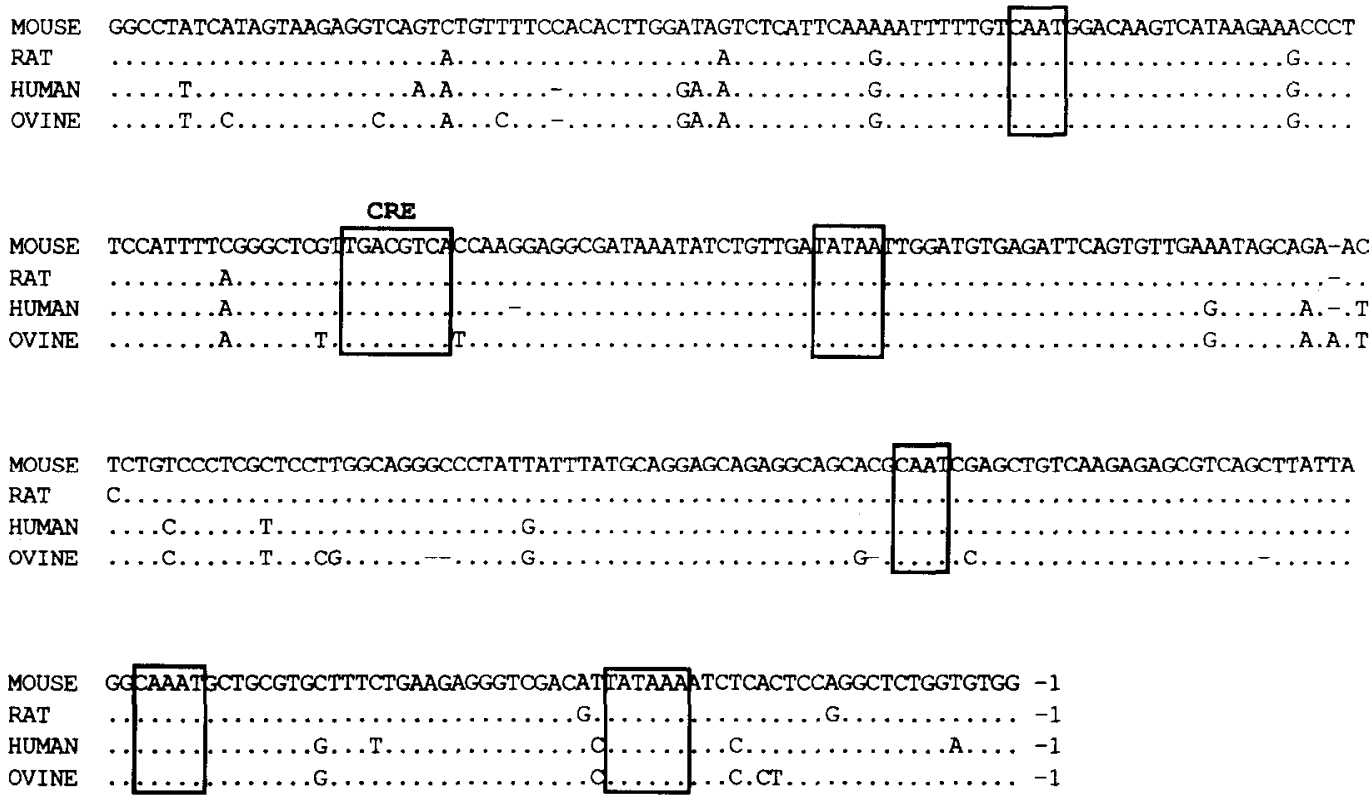

FIG. 5. Nucleic acid sequence homology within the CRH 5 ' flanking DNA of the mouse, rat, human, and ovine CRH genes. The sequence homology is shown across the first 336 nucleotides $5^{\prime}$ to the putative CRH mRNA cap site. The number -1 represents the first nucleotide $5^{\prime}$ to the assigned cap site. The dots represent conserved nucleotides and only the changes from the mouse sequence are shown. Hyphens represent positions of insertions or deletions within this region to best align the four genes. TATAA and CAAT boxes are outlined. The cAMP-responsive element (CRE) is boxed and indicated by CRE.

M13 vectors for restriction enzyme mapping and nucleotide sequence analysis as shown in Fig. 1. The complete nucleotide sequence of the mouse CRH gene is presented in Fig. 3. The mouse CRH gene appears to contain two exons, with an intron of 675 base pairs. The mouse $\mathrm{CRH}$ cDNA has not yet been isolated and characterized, so the assignment of the two exons is based on similarity of the mouse CRH gene structure to that of the human, rat, and ovine CRH genes (9-11). Additionally, Northern blot analysis (data not shown) has demonstrated the presence of a 1.4-kb mouse CRH mRNA, similar to the sizes of the human and rat CRH mRNA. The exon/intron boundaries have been assigned by homology to the human, rat, and ovine genes and in accordance with the donor and acceptor rules as described by Breathnach et al. (14).

The CRH mRNA cap sites have been mapped in ovine hypothalamus $(9)$, human placenta $(8,15)$, and rat brain (R. C. Thompson, personal communication). The putative mouse CRH mRNA cap site has been assigned by homology to the rat, human, and ovine genes in addition to the position of the TATAA and CAAT boxes 26 and 60 nucleotides upstream. Preliminary RNase I protection analyses using mouse brain RNA show that the assigned cap site is utilized in the mouse, in addition to several minor upstream transcription initiation sites (data not shown). Heterogeneity of transcription initiation has also been demonstrated for the human (8) and rat CRH genes.

The $3^{\prime}$ untranslated region of the mouse CRH gene contains three poly(A) addition signal sequences (AATAAA) at positions 1801,2184 , and 2247 . The rat and ovine $\mathrm{CRH}$ genes each contain four poly(A) addition signal sequences $(9,10)$, with the first three sequences corresponding to those found in the mouse $\mathrm{CRH}$ gene. CRH hypothalamic cDNA clones have been isolated which utilize the first three signal sequences in the ovine (6) and the second and third signal sequences in the rat $(7,10)$. The human $\mathrm{CRH}$ gene contains only two poly(A) addition signal sequences corresponding to the second and third sequences found in the mouse CRH sequence (11), and human placental CRH cDNA clones utilize the more $3^{\prime}$ of the two signal sequences (8). The functional significance of the multiple poly(A) addition signal sequences in the CRH gene has not been explored.

The amino acid sequence of the mouse $\mathrm{CRH}$ peptide was predicted based on the nucleotide sequence of the mouse CRH gene. As shown in Fig. 4, the mouse CRH peptide is identical at the amino acid level to the rat and human CRH peptides. Within the peptide-encoding region, the mouse gene contains 3 nucleotide changes from the rat DNA sequence (98\% homologous) and 10 nucleotide changes from the human gene ( $92 \%$ homologous), none of which cause an alteration in amino acid. The ovine CRH peptide contains 7 amino acid substitutions from the mouse, rat, and human CRH peptides.

Table 1 shows the nucleotide homologies (expressed as percentage) of specific regions of the mouse $\mathrm{CRH}$ gene when compared to the corresponding regions of the rat, human, and ovine $\mathrm{CRH}$ genes. The nucleotide homologies vary significantly across species and across different regions of the gene. The mouse CRH gene is very highly 

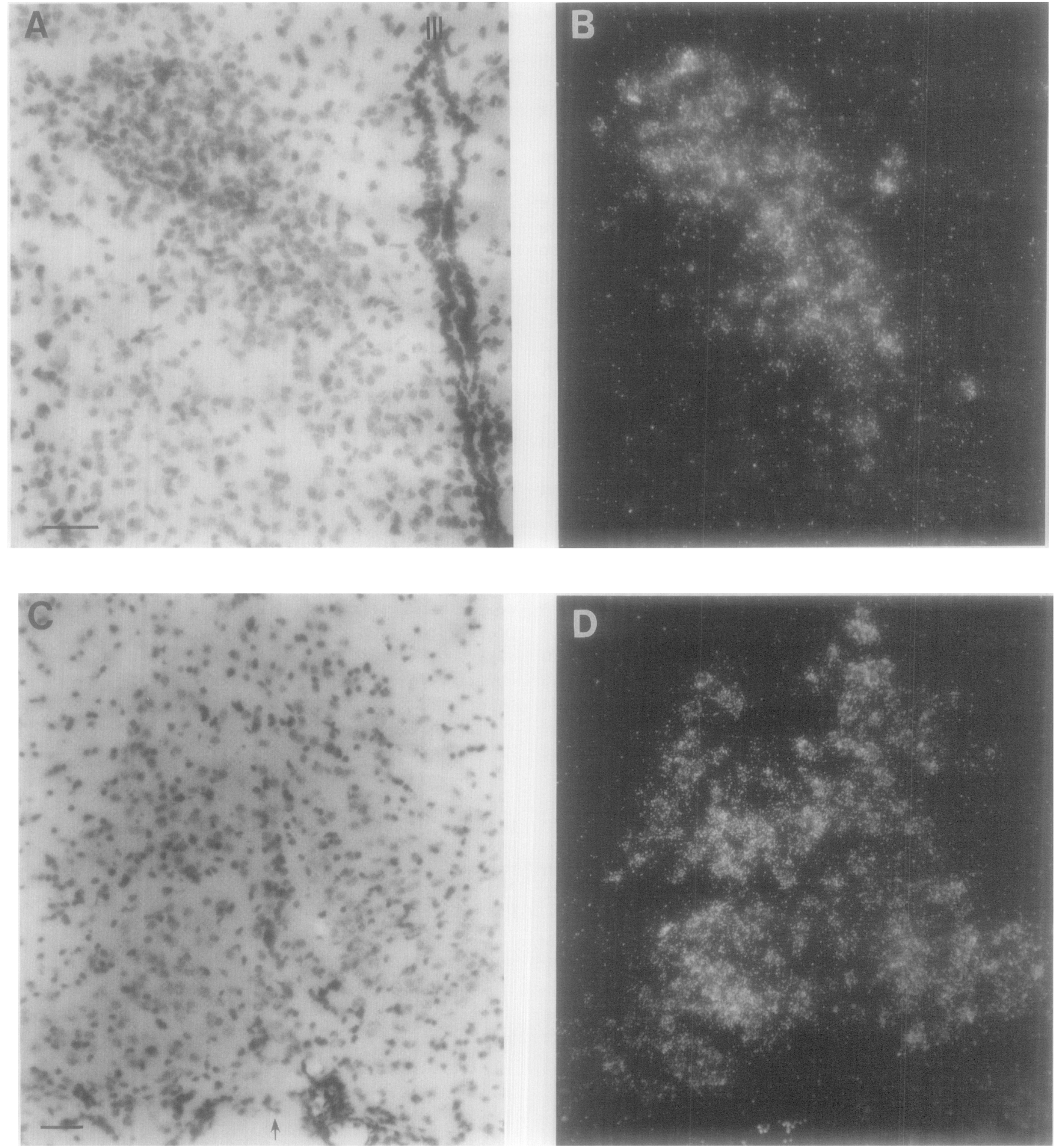

FIG. 6. In situ hybridization histochemical demonstration of CRH mRNA expression in parvocellular paraventricular nucleus of the hypothalamus and medial accessory olivary nucleus. The corresponding bright-field and dark-field photomicrographs from the parvocellular division of the paraventricular nucleus of the hypothalamus (A, B) and medial accessory olivary nucleus (C, D) are shown. B and D demonstrate hybridization histochemical localization of a ${ }^{35}$ S-labeled antisense CRH cRNA probe; $A$ and $C$ show the cresyl violet-stained sections to demonstrate the cellular architecture of the region. Magnification bar, $50 \mu \mathrm{m}$. III represents the position of the third ventricle and the arrow denotes the position of the midline. 
homologous to all regions of the rat sequence, with the lowest level of homology being $89 \%$ in the intronic sequences. In contrast, the mouse $\mathrm{CRH}$ gene shows high levels of homology to both the human and the ovine sequences in only two regions, the $\mathrm{CRH}$ peptide-encoding sequence and the $5^{\prime}$ flanking genomic sequences.

The mouse CRH $5^{\prime}$ flanking sequence is greater than $92 \%$ homologous at the nucleic acid level to the rat, human, and ovine CRH genes over the first $336 \mathrm{bp} 5^{\prime}$ to the mRNA cap site, more highly conserved than even the $\mathrm{CRH}$ peptide-encoding region. This nucleic acid sequence homology is shown in detail in Fig. 5. The $5^{\prime}$ flanking region of genes often contain transcriptional control elements responsible for tissue-specific, developmental, and hormonal regulation. The high degree of homology seen in this region of the CRH genes suggests that this DNA sequence has been conserved through evolution to maintain the important regulation of the $\mathrm{CRH}$ gene. Within this sequence are the TATAA and CAAT boxes at 26 and 60 nucleotides $5^{\prime}$ to the mRNA cap site. Additional TATAA and CAAT boxes are present further upstream and are conserved in all four CRH genes. Additionally, a 59bp DNA fragment which mediates cAMP regulation has been localized in the rat CRH gene (16) and the cAMPresponsive element (CRE) consensus sequence (TGACGTCA) within the localized DNA fragment is $100 \%$ homologous in all four species, suggesting that it may function in cAMP regulation of CRH expression in the rat, mouse, human, and ovine. A similar comparison of the CRE in the glycoprotein hormone $\alpha$-subunit gene from human, horse, rat, and mouse has shown that a one nucleotide change within the CRE consensus sequence can dramatically alter the cAMP regulation and tissuespecific expression of that gene (17).

The high level of homology within the $5^{\prime}$ flanking sequence of the CRH gene suggests that additional transcriptional control elements may also be present within this 336-bp DNA sequence. It is interesting to note that the level of homology between the four CRH genes decreases as one moves upstream from position -336 . Although the rat and mouse sequences are still relatively well conserved, the homology decreases dramatically between mouse and human or mouse and ovine, finding much smaller regions of homology interspersed with more divergent sequences.

\section{In Situ Hybridization Histochemical Localization of CRH Expression in Mouse Brain}

Immunocytochemical studies have demonstrated that the CRH peptide is present in widespread regions of the rat brain as well as in some peripheral tissues (18-23). CRH mRNA has been detected by Northern blot analysis in the hypothalamus, brain stem, cerebral cortex, midbrain, striatum, hippocampus, and olfactory bulb of the rat brain, as well as in rat spinal cord, adrenal, and testis $(10,24-26)$. In situ hybridization histochemical analyses in the rat have demonstrated the presence of $\mathrm{CRH}$ mRNA in the paraventricular nucleus of the hypothalamus, as well as in the inferior olivary nucleus and Barrington's nucleus $(13,25,27-29)$. In the mouse, CRH immunoreactivity has been detected in extracts of the median eminence, hypothalamus, amygdala, thalamus, frontal cortex, medulla/pons, and cerebellum by radioimmunoassay $(30,31)$, but mouse CRH mRNA levels have not previously been analyzed. Mouse brain, liver, lung, and spleen RNA were isolated and tested for CRH mRNA by RNase protection and Northern blot analyses. In both cases, CRH mRNA was detected only in mouse brain RNA (data not shown). In order to more carefully examine the expression of mouse CRH mRNA in brain, in situ hybridization analysis was performed using mouse brain sections containing the paraventricular nucleus of the hypothalamus or the inferior olive complex. As shown in Fig. 6, anti-sense mouse $\mathrm{CRH}$ probe hybridized to $\mathrm{CRH}$ mRNA in the parvocellular paraventricular nucleus of the hypothalamus (Fig. 6B) and in the medial accessory olivary nucleus (Fig. 6D) of the mouse brain. Hybridization was observed in both the principal and the accessory olivary nuclei of the mouse. Control experiments using sense hybridization probe showed no detectable expression in the paraventricular nucleus or inferior olivary complex. These results demonstrate that $\mathrm{CRH}$ is expressed in several of the same nuclei in the rat and mouse, suggesting that it functions as both a hypothalamic-releasing factor for $\mathrm{ACTH}$ in the anterior pituitary and a neurotransmitter or neuromodulator in the central nervous system of both species.

\section{ACKNOWLEDGMENTS}

We acknowledge the expert advice and assistance of Ms. Sharon Burke, Dr. James P. Herman, and Dr. Stanley J. Watson with the in situ hybridization histochemistry studies and Dr. Robert Thompson for critical reading of the manuscript. This work was supported by ADAMHA R03 MH46532 to S.A.C. and A.F.S. and NIH DK42730 to A.F.S. C.E.H. was supported by NRSA Training Grant 5T32GM07863.

\section{REFERENCES}

1. Vale, W., J. Vaughan, M. Smith, G. Yamamoto, J. Rivier, and C. Rivier (1983). Effects of synthetic ovine corticotropin-releasing factor, glucocorticoids, catecholamines, neurohypophysial peptides, and other substances on cultured corticotropic cells. Endocrinology 113: 1121-1131.

2. Vale, W., J. Spiess, C. Rivier, and J. Rivier (1981). Characterization of a 41-residue ovine hypothalamic peptide that stimulates secretion of corticotropin and beta-endorphin. Science 213: 1394-1397.

3. Koob, G. F., and F. E. Bloom (1985). Corticotropin-releasing factor and behavior. Fed. Proc. 44: 259-263.

4. Brown, M. R., and Fisher, L. A. (1985). Corticotropin-releasing factor: Effects on the autonomic nervous system and visceral systems. Fed. Proc. 44: 243-248.

5. Vale, W., C. Rivier, M. R. Brown, J. Spiess, G. Koob, L. Swanson, L. Bilezikjian, F. Bloom, and J. Rivier (1983). Chemical and biological characterization of corticotropin-releasing factor. Rec. Prog. Hormone Res. 39: 245-270. 
6. Furutani, Y., Y. Morimoto, S. Shibahara, M. Noda, N. Takahashi, T. Hirose, M. Asai, S. Inayama, H. Hayashida, T. Miyata, and S. Numa (1983). Cloning and sequence analysis of cDNA for ovine corticotropin-releasing factor precursor. Nature 301: 537-540.

7. Jingami, H., N. Mizuno, H. Takahashi, S. Shibahara, Y. Furutani, H. Imura, and S. Numa (1985). Cloning and sequence analysis of cDNA for rat corticotropin-releasing factor precursor. FEBS Lett. 191: 63-65.

8. Robinson, B. G., L. A. D'Angio, K. B. Pasieka, and J. A. Majzoub (1989). Preprocorticotropin releasing hormone: cDNA sequence and in vitro processing. Mol. Cell. Endocrinol. 61: 175-180.

9. Roche, P. J., R. J. Crawford, R. T. Fernley, G. W. Tregear, and J. P. Coghlan (1988). Nucleotide sequence of the gene coding for ovine corticotropin-releasing factor and regulation of its $\mathrm{mRNA}$ levels by glucocorticoids. Gene 71 : 421-431.

10. Thompson, R. C., A. F. Seasholtz, and E. Herbert (1987). Rat corticotropin-releasing hormone gene: Sequence and tissue-specific expression. Mol. Endocrinol. 1: 363-370.

11. Shibahara, S., Y. Morimoto, Y. Furutani, M. Notake, H. Takahashi, S. Shimizu, S. Horikawa, and S. Numa (1983). Isolation and sequence analysis of the human corticotropin-releasing factor precursor gene. $E M B O J$ J. 2: 775-779.

12. Southern, E. M. (1975). Detection of specific sequences among DNA fragments separated by gel electrophoresis. J.M.B. 98: 503517.

13. Herman, J. P., S. J. Weigand, and S. J. Watson (1990). Regulation of basal corticotropin-releasing hormone and arginine vasopressin messenger ribonucleic acid expression in the paraventricular nucleus: Effects of selective hypothalamic deafferentations. Endocrinology 127: 2408-2417.

14. Breathnach, R., C. Benoist, K. O'Hare, F. Gannon, and P. Chambon (1978). Ovalbumin gene: Evidence for a leader sequence in mRNA and DNA sequences at the exon-intron boundaries. Proc. Natl. Acad. Sci. USA 75: 4853-4857.

15. Frim, D. M., R. L. Emanuel, B. G. Robinson, C. M. Smas, G. K. Adler, and J. A. Majzoub (1988). Characterization and gestational regulation of corticotropin-releasing hormone messenger RNA in human placenta. $J$. Clin. Invest. 82: 287-292.

16. Seasholtz, A. F., R. C. Thompson, and J. O. Douglass (1988). Identification of a cyclic adenosine monophosphate-responsive element in the rat corticotropin-releasing hormone gene. Mol. Endocrinol. 2: 1311-1319.

17. Bokar, J. A., R. A. Keri, T. A. Farmerie, R. A. Fenstermaker, B. Andersen, D. L. Hamernik, J. Yun, T. Wagner, and J. H. Nilson (1989). Expression of the glycoprotein hormone a-subunit gene in the placenta requires a functional cyclic AMP responsive element, whereas a different cis-acting element mediates pituitary-8pecific expression. Mol. Cell. Biol. 9: 5113-5122.

18. Olschowka, J. A., T. L. O'Donohue, G. P. Mueller, and D. M. Jacobawitz (1982). Hypothalamic and extrahypothalamic distribution of CRH-like immunoreactive neurons in the rat brain. Neuroendocrinology 35: 305-308.
19. Merchenthaler, I., S. Vigh, P. Petrusz, and A. V. Schally (1982). Immunocytochemical localization of corticotropin-releasing factor (CRF) in the rat brain. Am. J. Anat. 165: 385-396.

20. Swanson, L. W., P. E. Sawchenko, J. Rivier, and W. Vale (1983). Organization of ovine corticotropin-releasing factor immunoreactive cells and fibers in the rat brain: An immunohistochemical study. Neuroendocrinology 36: 165-186.

21. Bloom, F. E., E. L. F. Battenberg, J. Rivier, and W, Vale (1982). Corticotropin releasing factor (CRF) immunoreactive neurons and fibers in rat hypothalamus. Regul. Peptides 4: 43-48.

22. Petrusz, P., I. Merchenthaler, J. L. Maderdrut, and P. U. Hertz (1985). Central and peripheral distribution of corticotropin-releasing factor. Fed. Proc. 44: 229-235.

23. Merchenthaler, I., M. A. Hynes, S. Vigh, A. V. Schally, and P. Petrusz (1983). Immunocytochemical localization of corticotropin releasing factor (CRF) in the rat spinal cord. Brain Res, 275: 373377.

24. Beyer, H. S., S. G. Matta, and B. M. Sharp (1988). Regulation of the mRNA for corticotropin-releasing factor in the paraventricular nucleus and other brain sites of the rat. Endocrinology 123: 21172123.

25. Imaki, T., J.-L. Nahan, C. Rivier, P. E. Sawchenko, and W. Vale (1991). Differential regulation of corticotropin-releasing factor mRNA in rat brain regions by glucocorticoids and stress. $J$. Neurosci. 11: 585-599.

26. Jingami, H., S. Matsukura, S. Numa, and H. Imura (1985). Effects of adrenalectomy and dexamethasone administration on the level of proprocorticotropin-releasing factor messenger ribonucleic acid (mRNA) in the hypothalamus and adrenocorticotropin/b-lipotropin precursor mRNA in the pituitary in rats. Endocrinology 117: 1314-1320.

27. Young, W. S., E. Mezey, and R. E. Siegel (1986). Quantitative in situ hybridization histochemistry reveals increased levels of corticotropin-releasing factor $\mathrm{mRNA}$ after adrenalectomy in rats. Neurosci. Lett. 70: 198-203.

28. Young, W. S., L. C. Walker, R. E. Powers, E. B. DeSouza, and D. L. Price (1986). Corticotropin-releasing factor mRNA is expressed in the inferior olives of rodents and primates. Brain Res. 387: 189-192.

29. Swanson, L. W., and D. M. Simmons (1989). Differential steroid hormone and neural influences on peptide mRNA levels in CRH cells of the paraventricular nucleus: A hybridization histochemical study in the rat. J. Comp. Neurol. 285: 413-435.

30. Hollander, C. S., T. Audhya, M. Russo, J. Passarelli, T. Nakane, and D. Schlesinger (1983). Levels of corticotropin-releasing factorlike immunoreactivity in mammalian hypothalamic an dextrahypothalamic brain tissue as determined with a monoclonal antibody to the ovine material. Endocrinology 112: 2206-2208.

31. Nakane, T., T. Audhya, C. S. Hollander, D. H. Schlesinger, P. Kardos, C. Brown, and J. Passarelli (1986). Corticotropin-releasing factor in extra-hypothalamic brain of the mouse: Demonstration by immunoassay and immunoneutralization of bioassayable activity. J. Endocrinol. 111: 143-149. 